[Chem Pharm Bull

35(12)4977-4980(1987) $]$

\title{
An Efficient Method for Preparing gem-Dimethylcyclopropanes from gem-Dibromocyclopropanes
}

\author{
Takashi Harayama, * Hideto Fukushi, Kazuhiro Ogawa, \\ Tetsuya Aratani, Satoshi Sonehara, \\ and FUMIO YONEDA*
}

Faculty of Pharmaceutical Sciences, Kyoto University, Sakyo-ku, Kyoto 606, Japan

(Received May 27, 1987)

\begin{abstract}
Reaction of gem-dibromocyclopropanes (1) with a higher-order organocuprate prepared from cuprous thiocyanate and methyllithium, followed by the addition of methyl odide in situ, readily afforded dimethylcyclopropanes (2) in good to excellent yields regardless of the functional group in 1
\end{abstract}

Keywords-higher-order organocuprate, dibromocyclopropane, dimethylcyclopropane, substitution reaction, dibromocarbene

In connection with studies of the total synthesis of a class of natural products that contain the gem-dimethylcyclopropane ring system, ${ }^{1)}$ several methods for preparing gemdimethylcyclopropanes have been developed, e.g. substitution of gem-dihalocyclopropanes with dimethylcopper lithium (Gilman's reagent), ${ }^{2)}$ addition of dimethylcarbene to olefins, ${ }^{3)}$ reaction of diphenylsulfonium isopropylide with conjugated carbonyl compounds, ${ }^{4)}$ and thermolysis of a pyrazolidine prepared by cycloaddition of dimethyldiazomethane to an olefin. ${ }^{5}$ Although dimethylcopper lithium has usually been used for this purpose, the reaction is occasionally sluggish, requiring a long reaction time. ${ }^{6-8)}$ Recently, Lipshurtz et al. have reported that the higher-order organocuprates react readily and efficiently with inactive alkyl iodides and bromides, affording substitution products. ${ }^{9-11)}$ An application of the Lipshutz method to gem-dibromocyclopropane was attempted in order to develop an efficient method for preparing gem-dimethylcyclopropane, and we have already reported that reaction of the higher-order organocuprates with 8,8-dibromobicyclo[5.1.0]octane, followed by the addition of methyl iodide in situ, afforded the desired dimethylated compound in good yield. ${ }^{12)}$ Subsequently, we attempted an application of the present method to other gemdibromocyclopropanes in order to examine its generality and usefulness. We describe here the results of this substitution reaction. ${ }^{13)}$

gem-Dibromocyclopropanes (1) except 1c were synthesized directly by reactions of the respective olefins with dibromocarbene prepared from bromoform and $40 \%$ sodium hydroxide solution in methylene chloride (method A) or from bromoform and potassium tertbutoxide in pentane (method B). The dibromo-silyl ether (1c) was synthesized by reaction of 1-cyclohexene-1-methanol with dibromocarbene (method A), followed by silylation with tertbutyldimethylsilyl (TBDMS) chloride. The yields are indicated in Table I. The structures of 1 were elucidated on the basis of their spectral data, and the stereostructure of $\mathbf{1 b}$ will be discussed later. In a previous paper, ${ }^{12)}$ we reported that $\mathrm{Me}_{2} \mathrm{Cu}(\mathrm{CN}) \mathrm{Li}_{2}$ was more reactive than $\mathrm{Me}_{2} \mathrm{Cu}(\mathrm{SCN}) \mathrm{Li}_{2}$ in the reaction with dibromobicyclo[5.1.0]octane, yielding overalkylated by-products. Therefore, the reactions of 1 with $\mathrm{Me}_{2} \mathrm{Cu}(\mathrm{SCN}) \mathrm{Li}_{2}-\mathrm{MeI}$ were examined. The results are listed in Table I, showing that reactions proceed smoothly to afford 
<smiles>[R]C1CCC2([R])[C@H](C1)C2(Br)Br</smiles>

1a: $\mathrm{R}^{1}=\mathrm{H}, \mathrm{R}^{2}=\alpha$-COOMe

$1 \mathrm{~b}: \mathrm{R}^{1}=\mathrm{H} ; \mathrm{R}^{2}=\beta-\mathrm{COOMe}$

1c : $\mathrm{R}^{1}=\mathrm{CH}_{2} \mathrm{OTBDMS}, \mathrm{R}^{2}=\mathrm{H}$

1d: $\mathrm{R}^{1}=\mathrm{OMe}, \mathrm{R}^{2}=\mathrm{H}$

1e $: \mathrm{R}^{1}=\mathrm{OMe}, \mathrm{R}^{2}=$ tert $-\mathrm{Bu}$

1g: $\left.\mathrm{R}^{1}=\mathrm{H}, \mathrm{R}^{2}=\mathrm{CH}^{\prime}=\frac{\mathrm{O}}{\mathrm{O}}\right]$

1h: $\mathrm{R}^{1}=\mathrm{H}, \mathrm{R}^{2}=\mathrm{CH}_{2} \mathrm{OH}$

1i : $\mathrm{R}^{1}=\mathrm{H}, \mathrm{R}^{2}=\mathrm{CH}_{2} \mathrm{OAc}$<smiles>[R]C1CCC2([R])[C@H](C1)C2(C)C</smiles>

$2 \mathrm{a}: \mathrm{R}^{1}=\mathrm{H}, \mathrm{R}^{2}=\alpha-\bar{C}$ COMe

$2 \mathrm{~b}: \mathrm{R}^{1}=\mathrm{H}, \mathrm{R}^{2}=\beta$-COOMe

2c $: \mathrm{R}^{1}=\mathrm{CH}_{2} \mathrm{OTBDMS}, \mathrm{R}^{2}=\mathrm{H}$

2d $: \mathrm{R}^{1}=\mathrm{OMe}, \mathrm{R}^{2}=\mathrm{H}$

$2 \mathrm{e}: \mathrm{R}^{1}=\mathrm{OMe}, \mathrm{R}^{2}=$ tert $-\mathrm{Bu}$

$2 \mathrm{~g}: \mathrm{R}^{1}=\mathrm{H}, \mathrm{R}^{2}=\mathrm{CH} \div \mathrm{O}$

2h: $\mathrm{R}^{1}=\mathrm{H}, \mathrm{R}^{2}=\mathrm{CH}_{2} \mathrm{OH}$

$2 \mathrm{i}: \mathrm{R}^{1}=\mathrm{H}, \mathrm{R}^{2}=\mathrm{CH}_{2} \mathrm{OAc}$<smiles>[R]C1([R])C2CCCC(C(C)=O)CCC21</smiles>

1f: $\mathrm{R}=\mathrm{Br}$

2f : $\mathrm{R}=\mathrm{Me}$

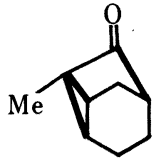

3<smiles>COC(=O)C1CCC2CC(C)(C)C2C1</smiles>

A

Chart 1

TABLE I. Yields of gem-Dibromocyclopropanes (1) and gem-Dimethylcyclopropanes (2)

\begin{tabular}{|c|c|c|c|c|c|c|}
\hline \multicolumn{2}{|c|}{ Products (Yield, \%) } & \multirow{3}{*}{$\frac{\text { Method }}{\text { A }}$} & \multicolumn{4}{|c|}{ Products (Yield, \%) } \\
\hline $1 \mathrm{a}$ & (62) & & $2 a$ & (91) & & \\
\hline lb & (34) & & 2b & (76) & 3 & (15) \\
\hline $1 c^{c)}$ & & & $2 c$ & (75) & & \\
\hline 1d & (91) & B & 2d & $(44)^{d)}$ & & \\
\hline $1 e^{b)}$ & (80) & B & $2 e^{b)}$ & (71) & & \\
\hline $1 f^{b)}$ & (51) & A & $2 f^{b)}$ & (73) & & \\
\hline $1 g^{b)}$ & (80) & A & $2 g^{b)}$ & (71) & & \\
\hline $1^{b)}$ & (40) & A & $\mathbf{2 h}^{b)}$ & (85) & & \\
\hline $1 i^{b)}$ & (86) & A & $2 \mathrm{i}^{b)}$ & (80) & $2 \mathbf{h}^{b)}$ & (12) \\
\hline
\end{tabular}

a) Isolated yields. The compounds indicated by $b$ ) were inseparable mixtures (about 1 to 1.5 ratio). c) See Experimental. d) The low yield was assumed to be because of the high volatility of $2 \mathrm{~d}$.

$\mathbf{2}$ in a good yield regardless of the functional group, such as ester, acetate, alkyl ether, silyl ether, acetal, or hydroxy group. The structures of products were elucidated on the basis of their spectral data. Dimethylation of $\mathbf{1 b}$ gave a small amount of the tricyclic ketone (3) produced via the metalated intermediate (A) along with the desired dimethylated compound (2b), indicating that $\mathbf{1 b}$ is a cis-dibromide. ${ }^{12)}$

In conclusion, the present method using $\mathrm{Me}_{2} \mathrm{Cu}(\mathrm{SCN}) \mathrm{Li}_{2}-\mathrm{MeI}$ is efficient for preparing the dimethyl compound (2) from the dibromo compound (1).

\section{Experimental}

The melting point of 1c was determined with a Yanagimoto micro melting point apparatus, and is uncorrected. Compounds for which no melting point is given are oily. The infrared (IR) spectra (IR $v_{\max }$ ) were determined on a Shimadzu IR-400 spectrometer in chloroform. The proton nuclear magnetic resonance $\left({ }^{1} \mathrm{H}-\mathrm{NMR}\right)$ spectra were obtained in chloroform- $d$ at $200 \mathrm{MHz}$ on a JEOL FX 200 instrument with chemical shifts being reported in parts per million downfield from tetramethylsilane as an internal standard $(\delta 0.0)$, and coupling constants in Hertz. Mass spectra (MS) were taken on a JEOL JMS 01SG-2 instrument (direct inlet) at $70 \mathrm{eV}$. All reactions were carried out under an atmosphere of argon. The reaction mixture was diluted with water and extracted with ether. The organic layer was washed with brine, dried over $\mathrm{MgSO}_{4}$, and filtered, then the filtrate was concentrated to dryness in vacuo. Column chromatography was carried out on silica gel (Wakogel C-200) or Aluminum oxide 90 (Merck, activity IIIII). Preparative thin layer chromatography (pTLC) was run on $20 \times 20 \mathrm{~cm}$ plates coated with a $0.25 \mathrm{~mm}$ layer of Merck Silica gel $\mathrm{GF}_{254}$.

General Procedure for Preparation of the Dibromides (1)_-Method A: Bromoform (17 mmol), tributylamine $(0.2 \mathrm{ml})$, and $40 \%$ aqueous sodium hydroxide $(8 \mathrm{ml})$ were added successively to a solution of an olefinic compound 
$(3 \mathrm{mmol})$ in methylene dichloride $(4 \mathrm{ml})$. The mixture was vigorously stirred under reflux for $2-6 \mathrm{~h}$.

Method B: Bromoform $(9 \mathrm{mmol})$ in pentane $(5 \mathrm{ml})$ was added to a suspension of tert-BuOK $(20 \mathrm{mmol})$ and an electron-rich olefin $(5 \mathrm{mmol})$ in pentane $(50 \mathrm{ml})$ at $0^{\circ} \mathrm{C}$. The reaction mixture was stirred for $2 \mathrm{~h}$ at $0{ }^{\circ} \mathrm{C}$. Yields are given in Table I.

Methyl (1RS,3SR,6SR)-7,7-Dibromobicyclo[4.2.0]heptane-3-carboxylate (1a) and Methyl (1RS,3RS,6SR)-7,7Dibromobicyclo[4.2.0] heptane-3-carboxylate (1b)-The residue in hexane was chromatographed on silica gel. Elution with hexane gave 1a. IR: $1720 \mathrm{~cm}^{-1} .{ }^{1} \mathrm{H}-\mathrm{NMR}: 3.67(3 \mathrm{H}, \mathrm{s}, \mathrm{COOMe})$. MS Calcd for $\mathrm{C}_{9} \mathrm{H}_{12} \mathrm{Br}_{2} \mathrm{O}_{2}: 309.9205$ $\left(\mathrm{M}^{+}\right)$. Found: 309.9212 . Successive elution with the same solvent gave 1b. IR: $1720 \mathrm{~cm}^{-1}$. ${ }^{1} \mathrm{H}-\mathrm{NMR}$ : 2.48 (1H, dddd, $J=14.4,10.3,4.4,1.9 \mathrm{~Hz}, \mathrm{CH}), 3.67$ (3H, s, COOMe). MS Calcd for $\mathrm{C}_{9} \mathrm{H}_{12} \mathrm{Br}_{2} \mathrm{O}_{2}: 309.9205$ (M ${ }^{+}$). Found: 309.9199 .

(1RS,6RS)-(7,7-Dibromobicyclo[4.1.0] hept-1-yl)methoxy-tert-butyldimethylsilane (1c)—(7,7-Dibromobicyclo[4.1.0]hept-1-yl)methanol was synthesized from 1-cyclohexene-1-methanol in $50 \%$ yield according to method A. $\mathrm{mp} 104-105^{\circ} \mathrm{C}$ (colorless plates from hexane). IR: $3580,3430 \mathrm{~cm}^{-1} .{ }^{1} \mathrm{H}-\mathrm{NMR}: 3.67\left(1 \mathrm{H}, \mathrm{d}, J=11.7 \mathrm{~Hz}_{1} \mathrm{CH}_{\mathrm{A}} \mathrm{H}_{\mathrm{B}} \mathrm{O}\right)$, $3.86\left(1 \mathrm{H}, \mathrm{d}, J=11.7 \mathrm{~Hz}, \mathrm{CH}_{\mathrm{A}} \mathrm{H}_{\mathrm{B}} \mathrm{O}\right)$. Anal. Calcd for $\mathrm{C}_{8} \mathrm{H}_{12} \mathrm{Br}_{2} \mathrm{O}: \mathrm{C}, 34.00 ; \mathrm{H}, 4.28$. Found: C, 33.83; $\mathrm{H}, 4.26$. A mixture of the above dibromide $(142 \mathrm{mg}, 0.5 \mathrm{mmol})$, imidazole $(102 \mathrm{mg}, 1.5 \mathrm{mmol})$, and TBDMS chloride (91 mg, $0.6 \mathrm{mmol})$ in dimethylformamide $(1 \mathrm{ml})$ was stirred at room temperature overnight. The residue in hexane was chromatographed on silica gel. Elution with hexane afforded $1 \mathrm{c}(190 \mathrm{mg}, 95 \%$ yield $)$. IR: $1095,840 \mathrm{~cm}^{-1} .{ }^{1} \mathrm{H}-\mathrm{NMR}$ : $0.06(3 \mathrm{H}, \mathrm{s}, \mathrm{Me}), 0.08(3 \mathrm{H}, \mathrm{s}, \mathrm{Me}), 0.91(9 \mathrm{H}, \mathrm{s}$, tert $-\mathrm{Bu}), 3.67\left(1 \mathrm{H}, \mathrm{d}, J=10.1 \mathrm{~Hz}, \mathrm{C}_{\mathrm{A}} \mathrm{H}_{\mathrm{B}} \mathrm{O}\right), 3.75(1 \mathrm{H}, \mathrm{d}, J=10.1 \mathrm{~Hz}$, $\mathrm{CH}_{\mathrm{A}} \mathrm{H}_{\mathrm{B}} \mathrm{O}$ ). MS Calcd for $\mathrm{C}_{14} \mathrm{H}_{26} \mathrm{Br}_{2} \mathrm{OSi}$ : $396.0120\left(\mathrm{M}^{+}\right)$. Found: 396.0122 .

(1RS,6RS)-7,7-Dibromo-1-methoxybicyclo[4.1.0]heptane (1d)—The residue in hexane was chromatographed on silica gel and elution with hexane provided 1d. IR: $1110-1070 \mathrm{~cm}^{-1} .{ }^{1} \mathrm{H}-\mathrm{NMR}: 3.47(3 \mathrm{H}, \mathrm{s}, \mathrm{OMe})$. MS Calcd for $\mathrm{C}_{8} \mathrm{H}_{12} \mathrm{Br}_{2} \mathrm{O}: 281.9264\left(\mathrm{M}^{+}\right)$. Found: 281.9265 .

7,7-Dibromo-4-tert-butyl-1-methoxybicyclo[4.1.0]heptane (1e)—The residue in hexane was chromatographed on aluminum oxide, and elution with hexane provided le. IR: $1120-1080 \mathrm{~cm}^{-1} .{ }^{1} \mathrm{H}-\mathrm{NMR}: 0.82,0.84$ (total $9 \mathrm{H}$, each s, tert-Bu), 3.46, 3.47 (total 3H, each s, OMe). MS Calcd for $\mathrm{C}_{12} \mathrm{H}_{20} \mathrm{Br}_{2} \mathrm{O}: 337.9863\left(\mathrm{M}^{+}\right)$. Found: 337.9865 .

Methyl 9,9-Dibromobicyclo[6.1.0]decane-4-carboxylate (1f)-The residue in hexane was chromatographed on silica gel. Elution with hexane afforded If. IR: $1720 \mathrm{~cm}^{-1} \cdot{ }^{1} \mathrm{H}-\mathrm{NMR}: 3.66,3.67$ (total $3 \mathrm{H}$, each s, COOMe). MS Calcd for $\mathrm{C}_{11} \mathrm{H}_{16} \mathrm{Br}_{2} \mathrm{O}_{2}: 337.9518\left(\mathrm{M}^{+}\right)$. Found: 337.9519 .

2-(7,7-Dibromobicyclo[4.1.0]hept-3-yl)-1,3-dioxolane (1g)—The residue in hexane was chromatographed on aluminum oxide. Elution with hexane and $5 \%$ ether in hexane gave $1 \mathrm{~g}$. IR: $1150-1120 \mathrm{~cm}^{-1} .{ }^{1} \mathrm{H}-\mathrm{NMR}: 3.84-3.94$ $\left(4 \mathrm{H}, \mathrm{m}, \mathrm{OCH}_{2} \mathrm{CH}_{2} \mathrm{O}\right), 4.58(1 \mathrm{H}, \mathrm{d}, J=4.4 \mathrm{~Hz}, \mathrm{CH})$. MS Calcd for $\mathrm{C}_{10} \mathrm{H}_{14} \mathrm{Br}_{2} \mathrm{O}_{2}: 323.9363$ ( $\mathrm{M}^{+}$). Found: 323.9378 .

7,7-Dibromobicyclo[4.1.0]heptane-3-methanol (1h) - The residue in hexane was chromatographed on aluminum oxide. Elution with $20-50 \%$ ether in hexane gave 1h. IR: $3600,3430 \mathrm{~cm}^{-1} .{ }^{1} \mathrm{H}-\mathrm{NMR}: 3.32-3.52(2 \mathrm{H}, \mathrm{m}$, $\mathrm{CH}_{2} \mathrm{O}$ ). MS Calcd for $\mathrm{C}_{8} \mathrm{H}_{12} \mathrm{Br}_{2} \mathrm{O}: 281.9264\left(\mathrm{M}^{+}\right)$. Found: 281.9263 .

3-Acetoxymethyl-7,7-dibromobicyclo[4.1.0]heptane (1i)-The residue in hexane was chromatographed on aluminum oxide. Elution with hexane and $10 \%$ ether in hexane provided 1i. IR: $1730 \mathrm{~cm}^{-1} .{ }^{1} \mathrm{H}-\mathrm{NMR}: 2.04(3 \mathrm{H}, \mathrm{s}$, $\mathrm{COMe}), 3.76-3.95\left(2 \mathrm{H}, \mathrm{m}, \mathrm{CH}_{2} \mathrm{OAc}\right)$. MS Calcd for $\mathrm{C}_{10} \mathrm{H}_{14} \mathrm{Br}_{2} \mathrm{O}_{2}: 323.9363\left(\mathrm{M}^{+}\right)$. Found: 323.9363 .

General Procedure for Reaction of Dibromides (1) with $\mathrm{Me}_{2} \mathrm{Cu}(\mathrm{SCN}) \mathrm{Li}_{2}-\mathrm{MeI}-$ Cuprous thiocyanate (345 mg, $2.84 \mathrm{mmol}$ ) dried under vacuum at $50^{\circ} \mathrm{C}$ for $2 \mathrm{~d}$ was placed in a flamed-dried $30 \mathrm{ml}$ two-necked flask, and dry ether $(2 \mathrm{ml})$ was added. Methyllithium $(5 \mathrm{ml}$ of $1.1 \mathrm{M}$ ether solution, $5.5 \mathrm{mmol})$ was added to the suspension at $-78^{\circ} \mathrm{C}$ and the mixture was gradually warmed to $-10^{\circ} \mathrm{C}$ over $30 \mathrm{~min}$. Then, the mixture was cooled to $-20^{\circ} \mathrm{C}$ and a solution of a bromide (1) in dry ether $(2.5 \mathrm{ml})$ and hexamethylphosphoric triamide $(0.11 \mathrm{ml})$ was added to the mixture at the same temperature. The reaction mixture was stirred for $1-2 \mathrm{~h}$ and methyl iodide $(1 \mathrm{ml})$ was added at $-50^{\circ} \mathrm{C}$. After $10 \mathrm{~min}$, the reaction mixture was quenched with saturated aqueous ammonium chloride at $-50^{\circ} \mathrm{C}$ and precipitates were filtrated off on a celite bed. The filtrate was extracted with ether and the organic layer was washed with $5 \%$ aqueous ammonia. Yields are given in Table $\mathrm{I}$.

Methyl (1RS,3SR,6SR)-7,7-Dimethylbicyclo[4.1.0]heptane-3-carboxylate (2a)—Purification of the residue by pTLC (hexane : AcOEt = 6:1) gave 2a. IR: $1725 \mathrm{~cm}^{-1} .{ }^{1} \mathrm{H}-\mathrm{NMR}: 0.65(2 \mathrm{H}, \mathrm{m}, 2 \times \mathrm{CH}), 0.93(3 \mathrm{H}, \mathrm{s}, \mathrm{Me}), 0.98(3 \mathrm{H}, \mathrm{s}$, Me), $3.66\left(3 \mathrm{H}, \mathrm{s}\right.$, COOMe). MS Calcd for $\mathrm{C}_{11} \mathrm{H}_{18} \mathrm{O}_{2}: 182.1308\left(\dot{\mathrm{M}}^{+}\right)$. Found: 182.1309 .

Methyl (1RS,3RS,6SR)-7,7-Dimethylbicyclo[4.1.0]heptane-3-carboxylate (2b) and (1RS,2SR,5RS,7SR)-7Methyltricyclo[3.2.1.0 ${ }^{2}{ }^{7}$ ]octan-6-one (3)-The residue was subjected to pTLC (hexane : AcOEt $=7: 1$ ). The upper zone gave $2 \mathrm{~b}$. IR: $1725 \mathrm{~cm}^{-1}$. ${ }^{1} \mathrm{H}-\mathrm{NMR}: 0.46(1 \mathrm{H}$, ddd, $J=9.2,6.5,2.4 \mathrm{~Hz}, \mathrm{CH}), 0.75(1 \mathrm{H}$, ddd, $J=9.2,9.2,5.5 \mathrm{~Hz}$, $\mathrm{CH}), 0.96(3 \mathrm{H}, \mathrm{s}, \mathrm{Me}), 0.99(3 \mathrm{H}, \mathrm{s}, \mathrm{Me}), 3.65(3 \mathrm{H}, \mathrm{s}, \mathrm{COOMe})$. MS Calcd for $\mathrm{C}_{11} \mathrm{H}_{18} \mathrm{O}_{2}: 182.1307$ ( $\left.\mathrm{M}^{+}\right)$. Found: 182.1310. The lower zone gave 3. IR: $1725 \mathrm{~cm}^{-1} .{ }^{1} \mathrm{H}-\mathrm{NMR}: 1.21(3 \mathrm{H}, \mathrm{s}, \mathrm{Me})$. MS Calcd for $\mathrm{C}_{9} \mathrm{H}_{12} \mathrm{O}: 136.0888\left(\mathrm{M}^{+}\right)$. Found: 136.0887.

(1RS,6RS)-(7,7-Dimethylbicyclo[4.1.0]hept-1-yl)methoxy-tert-butyldimethylsilane (2c)—The residue in hexane was chromatographed on aluminum oxide. Elution with hexane afforded $2 \mathrm{c}$. IR: $1080,840 \mathrm{~cm}^{-1}$. ${ }^{1} \mathrm{H}-\mathrm{NMR}: 0.01(3 \mathrm{H}$, $\mathrm{s}, \mathrm{Me}), 0.02(3 \mathrm{H}, \mathrm{s}, \mathrm{Me}), 0.38(1 \mathrm{H}, \mathrm{dd}, J=8.5,2.0 \mathrm{~Hz}, \mathrm{CH}), 0.89(9 \mathrm{H}, \mathrm{s}$, tert $-\mathrm{Bu}), 0.99(3 \mathrm{H}, \mathrm{s}, \mathrm{Me}), 1.08(3 \mathrm{H}, \mathrm{s}, \mathrm{Me})$, $3.41\left(1 \mathrm{H}, \mathrm{d}, J=10.0 \mathrm{~Hz}, \mathrm{C}_{\mathrm{A}} \mathrm{H}_{\mathrm{B}} \mathrm{O}\right), 3.58\left(1 \mathrm{H}, \mathrm{d}, J=10.0 \mathrm{~Hz}, \mathrm{CH}_{\mathrm{A}} \underline{\mathrm{H}}_{\mathrm{B}} \mathrm{O}\right)$. MS Calcd for $\mathrm{C}_{16} \mathrm{H}_{32} \mathrm{OSi}: 268.2222\left(\mathrm{M}^{+}\right)$. Found: 268.2206.

(1RS,6RS)-1-Methoxybicyclo[4.1.0]heptane (2d)—The residue in hexane was chromatographed on silica gel. 
Elution with hexane gave 2d. IR: $1140 \mathrm{~cm}^{-1} .{ }^{1} \mathrm{H}-\mathrm{NMR}$ : $0.68(1 \mathrm{H}, \mathrm{dd}, J=8.9,2.0 \mathrm{~Hz}, \mathrm{CH}), 0.99(3 \mathrm{H}, \mathrm{s}, \mathrm{Me}), 1.16(3 \mathrm{H}$, s, Me), $3.24(3 \mathrm{H}, \mathrm{s}, \mathrm{OMe})$. MS Calcd for $\mathrm{C}_{10} \mathrm{H}_{18} \mathrm{O}: 154.1358\left(\mathrm{M}^{+}\right)$. Found: 154.1358.

4-tert-Butyl-1-methoxy-7,7-dimethylbicyclo[4.1.0]heptane (2e)—The residue in hexane was chromatographed on silica gel. Elution with hexane 2e. IR: $1080 \mathrm{~cm}^{-1} .{ }^{1} \mathrm{H}-\mathrm{NMR}$ : $0.80,0.82$ (total $9 \mathrm{H}$, each s, tert-Bu), $0.98,0.99$ (total $3 \mathrm{H}$, each s, Me), 1.16, 1.17 (total $3 \mathrm{H}$, each s, Me), 3.23, 3.25 (total $3 \mathrm{H}$, each s, OMe). MS Calcd for $\mathrm{C}_{14} \mathrm{H}_{26} \mathrm{O}$ : $210.1984\left(\mathrm{M}^{+}\right)$. Found: 210.1978 .

Methyl 9,9-Dimethylbicyclo[6.1.0]decane-4-carboxylate (2f)_-Purification of the residue by pTLC (hexane: $\mathrm{AcOEt}=10: 1)$ gave 2f. IR: $1720 \mathrm{~cm}^{-1}$. ${ }^{1} \mathrm{H}-\mathrm{NMR}: 0.20-0.51(2 \mathrm{H}, \mathrm{m}, 2 \times \mathrm{CH}), 0.93(3 \mathrm{H}, \mathrm{s}, \mathrm{Me}), 1.01(3 \mathrm{H}, \mathrm{s}, \mathrm{Me})$, 3.65, 3.66 (total $3 \mathrm{H}$, each s, COOMe). MS Calcd for $\mathrm{C}_{13} \mathrm{H}_{22} \mathrm{O}_{2}: 210.1620\left(\mathrm{M}^{+}\right)$. Found: 210.1627 .

2-(7,7-Dimethylbicyclo[4.1.0]hept-3-yl)-1,3-dioxolane (2g) - The residue in hexane was chromatographed on aluminum oxide and elution with hexane afforded $2 \mathrm{~g}$. IR: $1150 \mathrm{~cm}^{-1}$. ${ }^{1} \mathrm{H}-\mathrm{NMR}: 0.41-0.90(2 \mathrm{H}, \mathrm{m}, 2 \times \mathrm{CH}), 0.93$, 0.95 (total $3 \mathrm{H}$, each s, Me), $0.98(3 \mathrm{H}, \mathrm{s}, \mathrm{Me}), 3.79-4.00\left(4 \mathrm{H}, \mathrm{m}, \mathrm{OC}_{2} \mathrm{CH}_{2} \mathrm{O}\right), 4.57(1 \mathrm{H}, \mathrm{d}, J=4.9 \mathrm{~Hz}, \mathrm{CH}) . \mathrm{MS}$ Calcd for $\mathrm{C}_{12} \mathrm{H}_{20} \mathrm{O}_{2}$ : $196.1463\left(\mathrm{M}^{+}\right)$. Found: 196.1469 .

7,7-Dimethylbicyclo[4.1.0]heptane-3-methanol (2h)_- The residue in hexane was chromatographed on silica gel. Elution with $5 \%$ ether in hexane provided $2 \mathrm{~h}$. IR: $3620,3440 \mathrm{~cm}^{-1} \cdot{ }^{1} \mathrm{H}-\mathrm{NMR}: 0.42-0.91(2 \mathrm{H}, \mathrm{m}, 2 \times \mathrm{CH}), 0.93$, 0.94 (total $3 \mathrm{H}$, each s, Me), $0.99(3 \mathrm{H}, \mathrm{s}, \mathrm{Me}), 3.22-3.52\left(2 \mathrm{H}, \mathrm{m}, \mathrm{CH}_{2} \mathrm{O}\right)$. MS Calcd for $\mathrm{C}_{10} \mathrm{H}_{18} \mathrm{O}: 154.1358\left(\mathrm{M}^{+}\right)$. Found: 154.1355.

3-Acetoxymethyl-7,7-dimethylbicyclo[4.1.0]heptane (2i) and $2 \mathrm{~h}$-The residue in hexane was chromatographed on silica gel. Elution with $5 \%$ ether in hexane gave 2i. IR: $1720 \mathrm{~cm}^{-1} .{ }^{1} \mathrm{H}-\mathrm{NMR}$ : $0.42-0.85(2 \mathrm{H}, \mathrm{m}, 2 \times \mathrm{CH}), 0.93$, 0.94 (total $3 \mathrm{H}$, each s, Me), $0.98(3 \mathrm{H}, \mathrm{s}, \mathrm{Me}), 2.05(3 \mathrm{H}, \mathrm{s}, \mathrm{COMe}), 3.78-3.98\left(2 \mathrm{H}, \mathrm{m}, \mathrm{C}_{2} \mathrm{OAc}\right)$. MS Calcd for $\mathrm{C}_{12} \mathrm{H}_{20} \mathrm{O}_{2}: 196.1463\left(\mathrm{M}^{+}\right)$. Found: 196.1467 . Elution with $40 \%$ ether in hexane gave $\mathbf{2 h}$. This compound was identical with the alcohol (2h) on the basis of IR and ${ }^{1} \mathrm{H}-\mathrm{NMR}$ spectral comparisons.

\section{References and Notes}

1) T. K. Devon and A. I. Scott, "Handbook of Naturally Occurring Compounds," Vol. II, Academic Press, New York and London, 1972.

2) G. H. Posner, "Organic Reactions," Vol. 22, ed. by W. G. Dauben, John Wiley and Sons, Inc., New York, 1975 , p. 253 and references cited therein.

3) P. Fischner and G. Shaefer, Angew. Chem., Int. Ed. Engl., 20, 863 (1981).

4) E. J. Corey and M. Jautelat, J. Am. Chem. Soc., 89, 3912 (1967).

5) M. Saha, B. Bagby, and K. M. Nicholas, Tetrahedron Lett., 27, 915 (1986) and references cited therein.

6) M. D. Taylor, G. Minaskanıan, K. N. Winzenberg, P. Santone, and A. B. Smith III, J. Org. Chem., 47, 3960 (1982).

7) E. J. Corey and G. H. Posner, J. Am. Chem. Soc., 89, 3911 (1967).

8) J. A. Marshall and J. A. Ruth, J. Org. Chem., 39, 1971 (1974).

9) B. H. Lipshutz, R. S. Wilhelm, J. A. Kozlowski, and D. Parker, J. Org. Chem., 49, 3928 (1984).

10) B. H. Lipshutz, J. A. Kozlowski, and R. S. Wilhelm, J. Org. Chem., 48, 546 (1983).

11) B. H. Lipshutz, R. S. Wilhelm, and J. A. Kozlowski, Tetrahedron, 40, 5005 (1984).

12) T. Harayama, H. Fukushı, T. Aratani, K. Ogawa, T. Murata, and F. Yoneda, Chem. Pharm. Bull., 35, 1777 (1987).

13) T. Harayama, H. Fukushı, K. Ogawa, and F. Yoneda, Chem. Pharm. Bull., 33, 3564 (1985). 